\title{
Correlation between Different Morphological Traits of Pomegranate (Punica grantum)
}

\author{
Shaili Kumari*, M.R. Dinesh, B.N.S. Murthy, K.M. Shankaran, \\ D.C. Lakshmana Reddy, K.S. Shivashankara, Kanupriya and K.K. Upreti
}

Division of Fruit Crops, ICAR-IIHR, Hesaraghatta, Bengaluru, 560089, Karnataka, India

*Corresponding author:

\section{A B S T R A C T}

\begin{tabular}{|c|c|}
\hline Key & $\begin{array}{l}\text { nate is quite popu } \\
\text { arils. Pomegrana }\end{array}$ \\
\hline $\begin{array}{l}\text { Morpl } \\
\text { charac } \\
\text { Correl } \\
\text { param } \\
\text { Analy } \\
\text { Variar } \\
\text { charac }\end{array}$ & $\begin{array}{l}\text { Iran. Total } 151 \text { pomegranate genotypes along with their hybrid parents (Bhagwa, DF, } \\
\text { Nana) combinely } 154 \text { used for morphological characterization. Total } 13 \text { morphological } \\
\text { parameters were used for characterization and Analysis of Variance, mean comparison and } \\
\text { simple correlations were analysed. Significance differences }(\mathrm{P} \leq 0.05) \text { were found among } \\
\text { all the genotypes of pomegranate. Highest critical differences at } 5 \% \text { were } 13.21 \text { (Fruit } \\
\text { weight), } 11.98 \text { (Aril } \%), 2.552 \text { Thorn }\{\text { No/Shoot length }(\mathrm{m})\} \text { recorded and lowest in leaf }\end{array}$ \\
\hline Art & \\
\hline $\begin{array}{l}\text { Accep } \\
10 \text { De } \\
\text { Availa } \\
10 \text { Jan }\end{array}$ & $\begin{array}{l}\text { related to each other }(r=-0.42) \text {. Those fruit have larger size and weight have less seed } \\
\text { diness. Fruit characteristics are negatively correlated with leaf characteristics }(r=- \\
\text { 2).The largest the leaf size smallest the fruit size. }\end{array}$ \\
\hline
\end{tabular}

\section{Introduction}

Pomegranate is quite popular among consumer for its striking, sweet acidic taste and refreshing arils. Pomegranate is one of the ancient fruit crops which were originated in Iran. Now a day its demand is growing for the processing purpose (Pruthi and saxena, 1984). It can produce fruit in Tropical, subtropical and temperate conditions. Pomegranate can produce fruit up to $1800 \mathrm{msl}$ (Sharma and Sharma 1990).Pomegranate is classified under often cross pollinated crop but still have narrow genetic base, only two species existing under Punicaceae family Punica granatum and Punica protopunica. So far a very less number of varieties were developed through systematic hybridization. Earlier reported chromosome number of cultivated species Punica granatum was $2 \mathrm{n}=2 \mathrm{x}=16,18$ (Singh, 2004). Shieldi et al., (2005) observed chromosome number in his study was $2 n=2 x=16$.Universely pomegranate has gained commercial importance for their physico chemical characteristics. Pomegranate fruit colour varies from yellow (Ganesh) to red 
(Bhagwa) and average fruit weight was about 250-300g (Patil et al., 2013). Aril colour varies from white to dark red. Ovate, oval and round fruit shape was observed in pomegranate. Aril taste varies from sweet (Bhagwa) to sour insipid (Daru, Nana) (Saxena et al., 1987).TSS recorded in Ganesh, Arakta and kesar was $14.5^{0} \mathrm{~B}, 13^{0} \mathrm{~B}, 14^{0} \mathrm{~B}$ with $0.57,0.59$, and 0.59 per cent acidity, 10.4, 10.2 and $9.65 \%$ total sugars, $8.40,8.00$ and $7.3 \%$ reducing sugars, 2.00,2.20 and 2.35 $\%$ non-reducing sugars (Patil et al., 2005). Jagtap et al., (1992) analysed 29 pomegranate cultivars for their growth and fruit characters and classify the genotypes into the following growth habit (spreading, erect, semispreading), foliage nature (Deciduous, semideciduous, evergreen). He observed that growth habit of tree based on height to spread ratio. Thakur et al., (2010) used twenty pomegranate cultivars from Iran for their biochemical traits and antioxidant activity. The experiment reported that significant differences among the cultivars. Ercisli et al., (2011) evaluated pomegranate fruit physical characteristics to recognise that which parameters are related to size. Fruit parameters, like fruit volume and weight, aril weight and number, pericarp weight, seed weight, and juice/pulp content, were assessed in a sample of fruits of variable sizes of 'Wonderful' pomegranate. Results showed that fruit volume, fruit weight, and total aril weight were correlating each other. Any one of these characteristics can be considered as an indicator of fruit size. Among them arils numbers per fruit was highly correlated with fruit size.

\section{Materials and Methods}

Total 151 pomegranate genotypes along with their hybrid parents (Bhagwa, DF, Nana) combinely 154 conserved at Division of Fruit crops, IIHR, Bengaluru, were be used for morphological characterization. The details of this genotype are given in Table 1 is used for characterization. Total 13 morphological parameters were used for characterization; these are as follows plant height, plant spread, growth habit, thorn no/shoot length, Fruit weight $(\mathrm{g})$, Fruit length $(\mathrm{cm})$, Fruit width (cm), Fruit peel thickness $(\mathrm{mm})$, Aril $(\%)$, Seed hardiness $(\mathrm{N} / \mathrm{mm})$, Leaf blade length $(\mathrm{cm})$, Leaf blade width $(\mathrm{cm})$, Petiole length $(\mathrm{mm})$. Analysis of Variance, mean comparison and simple correlations were analysed in SPSS and SAS software (Mehr et al., 2012).

\section{Results and Discussion}

Significance differences $(\mathrm{P} \leq 0.05)$ were found among all the genotypes of pomegranate (Table 2). There was the quite variation in the mean and range of different plant characteristics which enlisted in Table 3. Highest critical differences at 5\% were 13.21 (Fruit weight), 11.98 (Aril \%), 2.552Thorn $(\mathrm{No} /$ Shoot length $(\mathrm{m}))$ recorded and lowest in leaf blade width $0.143,0.145$ in leaf blade length, 0.456 in fruit length and 0.48 in seed hardiness respectively. The result obtained was quite similar to result obtained in the research of (Karimi et al., 2009).

The correlation between each pair of trait was calculated enlisted in Table 3. Vegetative growth parameters like plant height and plant spread was positively correlated with each other. Correlation between plant height and plant spread $(r=+0.23)$. Growth habit of plant was determined based on height and spread ration (Jagtap et al., 1992). Thorn (No/shoot length (m)) was one of the important vegetative characteristics of pomegranate and it negatively correlated with plant spread and growth habit $(\mathrm{r}=-0.085)$ and $(\mathrm{r}=-0.20)$. Leaf parameter was positively correlated with each other. Leaf length and leaf breadth are significantly correlated with each other ( $r=$ +0.81 ) and leaf width and leaf length was positively correlated petiole length $(\mathrm{r}=+0.75)$ and $(r=+0.88)$. 
Table.1 Pomegranate genotypes used for morphological characterization

\begin{tabular}{|c|c|}
\hline $\begin{array}{l}\text { Group of } \\
\text { genotypes }\end{array}$ & Genotypes name \\
\hline $\begin{array}{l}\text { Hybrid } \\
\text { (Bhagwa } x \\
\text { DF x Nana) }\end{array}$ & $\begin{array}{rrr}9 / 8,14 / 20,18 / 16, & 9 / 14, & 15 / 2,18 / 20,9 / 16,15 / 4 \\
9 / 7,11 / 10,15 / 7,11 / 812 / 5,15 / 18,12 / 6, & 12 / 10,16 / 3, \\
13 / 6,12 / 12,16 / 4,14 / 8,13 / 3,16 / 5,15 / 5 & 13 / 4,16 / 10,14 / 2,13 / 11,16 / 20, \\
15 / 1,13 / 12,17 / 6,16 / 1,13 / 20,17 / 13,17 / 2 & \\
14 / 6,17 / 18,17 / 3,14 / 11,9 / 6,17 / 7,14 / 12,18 / 1,18 / 3,14 / 16,18 / 4,18 / 5,14 / 19,18 / 10\end{array}$ \\
\hline $\begin{array}{l}\text { Mutant } \\
\text { (Gamma } \\
\text { Irradiated } \\
\text { Bhagwa } \\
\text { cutting) }\end{array}$ & 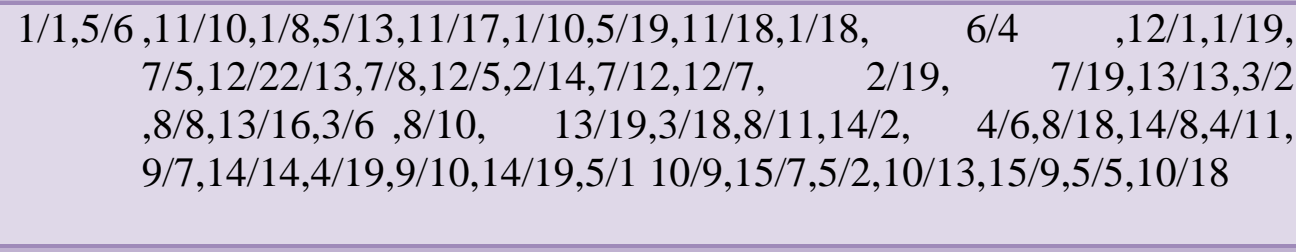 \\
\hline $\begin{array}{l}\text { Wild (Daru } \\
\text { type) }\end{array}$ & 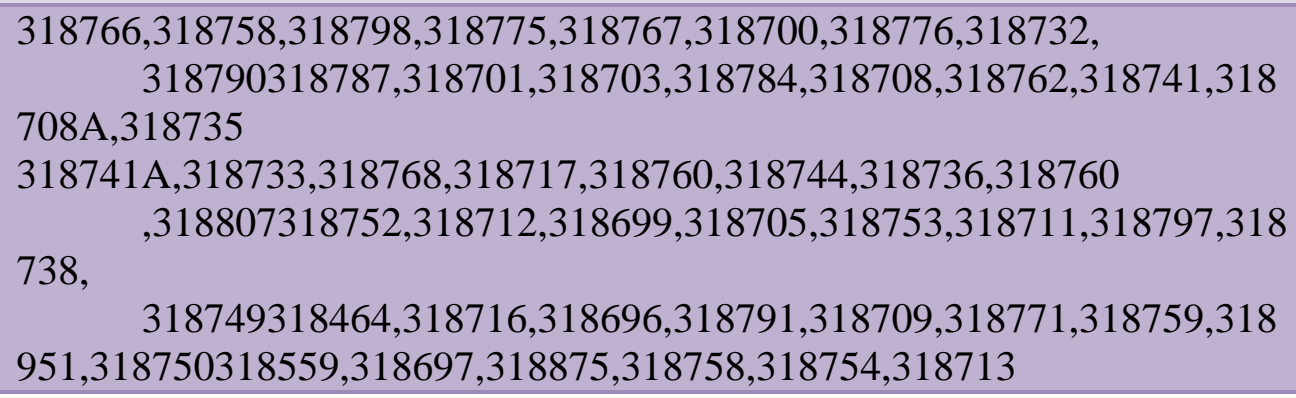 \\
\hline
\end{tabular}

Table.2 Evaluation of pomegranate genotypes for their economic traits

\begin{tabular}{|c|c|c|c|c|c|c|}
\hline \multirow{2}{*}{$\begin{array}{l}\text { Sl. } \\
\text { No. }\end{array}$} & \multirow[t]{2}{*}{ Parameter } & \multirow[t]{2}{*}{ Mean } & \multicolumn{2}{|c|}{ Range } & \multirow{2}{*}{$\begin{array}{c}\text { SEm } \\
\pm\end{array}$} & \multirow{2}{*}{$\begin{array}{l}\text { C.D. } \\
\text { at } 5 \%\end{array}$} \\
\hline & & & Minimum & Maximum & & \\
\hline 1. & Plant height (m) & $3.3(\mathrm{~m})$ & 0.535 (Nana) & $4.74(318760)$ & 0.041 & 0.115 \\
\hline 2. & Plant spread(m) & $2.05(\mathrm{~m})$ & 0.555 (Nana) & $3.55(318766)$ & 0.027 & 0.074 \\
\hline 3. & $\begin{array}{l}\text { Thorn(No /Shoot } \\
\text { length }(\mathrm{m})\end{array}$ & 16 & $5(12 / 5)$ & $38(14 / 11)$ & 0.902 & 2.552 \\
\hline 4. & Fruit weight(g) & 98.30 & $20.05(318701)$ & $362.78(14 / 12)$ & 4.724 & 13.21 \\
\hline 5. & Fruit length $(\mathrm{cm})$ & 5.63 & $3.4(318735)$ & 8.93(318713) & 0.163 & 0.456 \\
\hline 6. & Fruit width $(\mathrm{cm})$ & 5.24 & $3.55(318735)$ & $9.033(318713)$ & 0.171 & 0.477 \\
\hline 7. & $\begin{array}{l}\text { Fruit Peel } \\
\text { Thickness(mm) }\end{array}$ & 2.35 & $1.15(18 / 1)$ & $4.305(14 / 12)$ & 0.068 & 1.913 \\
\hline 8. & Aril(\%) & 235 & $57(318699)$ & $778(15 / 18)$ & 4.11 & 11.98 \\
\hline 9. & $\begin{array}{l}\text { Seed } \\
\text { hardiness(N/mm) }\end{array}$ & 10.56 & 4.4(Bhagwa) & 19.6(318750) & 0.172 & 0.48 \\
\hline 10. & $\begin{array}{l}\text { Leaf blade } \\
\text { length }(\mathrm{cm})\end{array}$ & 4.48 & 1.72(Nana) & $6.35(318699)$ & 0.052 & 0.145 \\
\hline 11. & $\begin{array}{l}\text { Leaf blade } \\
\text { width }(\mathrm{cm})\end{array}$ & 1.44 & 0.65 (Nana) & 2.43(318699) & 0.044 & 0.143 \\
\hline 12. & Petiole length $(\mathrm{mm})$ & 4.13 & 1.52 (Nana) & $6.46(318699)$ & 0.059 & 0.164 \\
\hline
\end{tabular}


Table.3 Bivariate correlations among 13 morphological traits in pomegranate genotypes

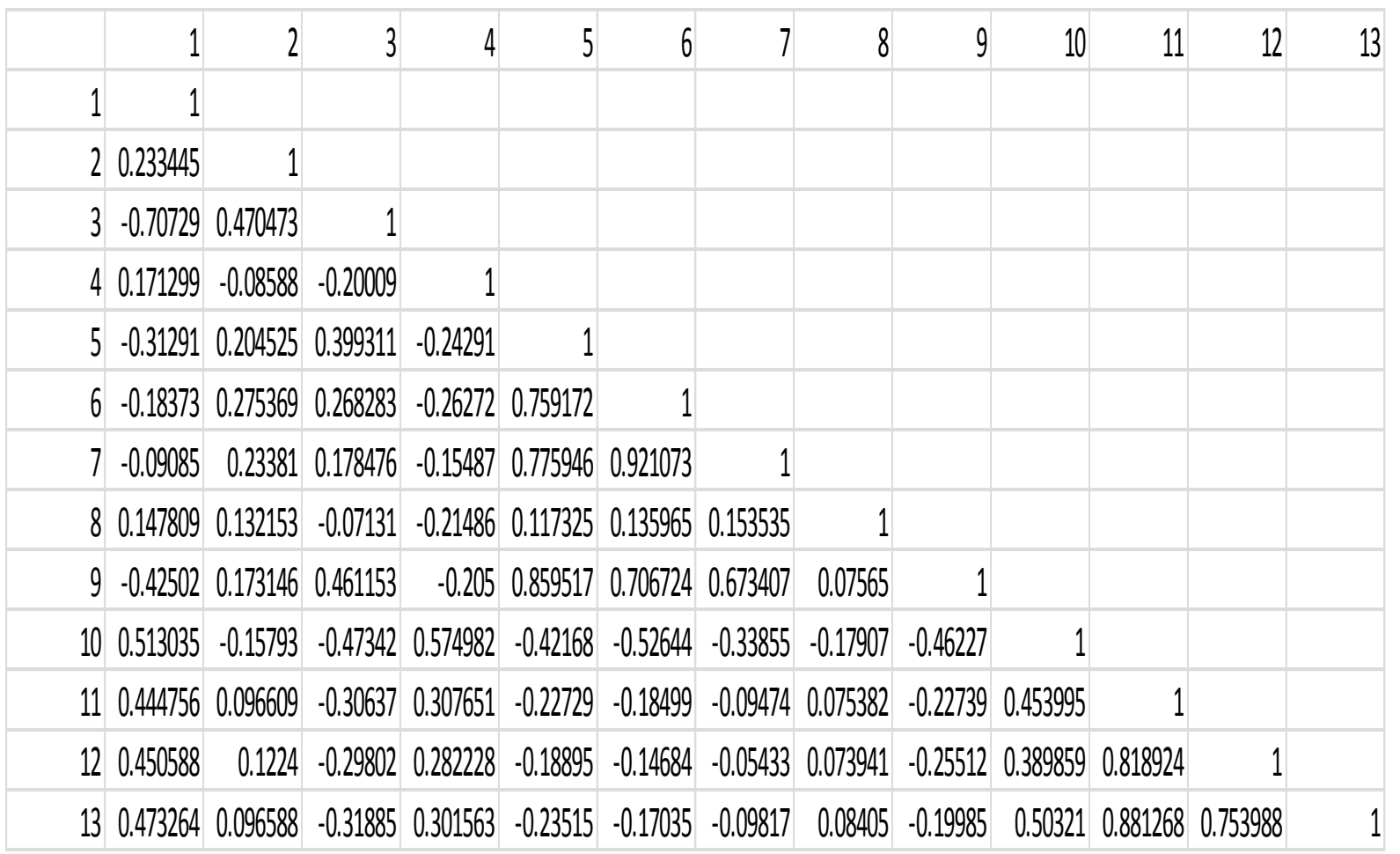

Plant growth habit (Height/Spread) was positively correlated with each other $(\mathrm{r}=+$ 0.67).Mars (1996) correlated leaf colour with sour and sweet taste of fruit. The cultivars with green and smaller leaves are sourer and sweet cultivars have lighter leaves and larger leaves. Fruit characters like fruit weight, fruit length, fruit breadth and aril (\%) are positively correlated to each other. Fruit weight significantly correlated to fruit length and breadth $(\mathrm{r}=+0.75), \quad(\mathrm{r}=+0.77)$.Fruit weight was positively correlated with fruit peel thickness $(r=+0.11)$. Fruit weight and seed hardiness was negatively correlated to each other $(\mathrm{r}=-0.42)$. Those fruit have larger size and weight have less seed hardiness. Fruit characteristics are negatively correlated with leaf characteristics $(\mathrm{r}=-0.22)$. The largest the leaf size smallest the fruit size. Zamini et al., (2006) studied that fruit quantitative and qualitative characteristic in pomegranate. He observed that number of seed in fruit was negatively correlated to the fruit weight ( $\mathrm{r}=-72)$ and positively correlated with fruit length $(\mathrm{r}=+74)$.

\section{References}

Ercisli, S., Gadze J., Agar G., Yildirim N. and Hizarci Y., (2011). Genetic relationships among wild pomegranate (Punica granatum L) genotypes from Coruh Valley in Turkey. Genetic of Molecular Research, 10: 459-464.

Jagtap D.B., Desai U.T. and Masalkar S.D., (1992). Assessment of pomegranate germplasm for vegetative and fruit characters. Annals of Arid Zone, 31(3): 217-219.

Karimi, H.R., Zamani, Z., Ebadi, A., Fatahi. M.R., (2009). Morphological diversity of Pistacia species in Iran. Genetic Resource Crop Evolution, 56: 561-571.

Mars, M. (1996). Pomegranate genetic resources in the Mediterranean region. Proceedings plant genetic resources 
Meeting, Tenerife, spain 2-4oct: 345354.

Mehr, S.A., Maassoumi, AA., Saidi, A., Kazempou $\mathrm{O}$ and Ghorbani, N.M. (2012). Morphological cladistic analysis of some bifurcate hairy sections of Astragalus (Fabaceae) in Iran. Turkish journal of botany, 15: 25-38

Patil A.B., Matapathi S.S., Nirmalnath P.J. and Patil S.R. (2005). Screening of pomegranate (Punica granatum L.) cultivar for wine production. Beverage and Food World, 32(2): 56-58.

Patil P., Sayed H. M., Joshi A. A. and Jadhav B. A. (2013). Comparative evaluation of physico-chemical properties of two varieties of pomegranate fruits Ganesh and Arakta. African Journal of Food Science, 7(11): 428-430.

Pruthi J.S. and Saxena A.K. (1984). Studies on anardana (dried pomegranate seeds). Journal of Food Science Technology, 21:296-299.

Saxena A.K., Manan J.K., and Berry S.K., (1987). Pomegranates: post-harvest technology, chemistry and processing. Indian Food Packer, 41: 43-60.
Sharma, S.D. and Sharma, V.K. (1990) Variation for chemical characters in some promising strains of wild pomegranate (Punica granatum L.). Euphytica, 49(2): 131-133.

Shieldi, M., Noormohammadi, Z., Saneghi, A. and Shahreiyari, Z. H. (2005).RAPD analysis of eleven Iranian pomegranate (Punica granatum L.) cultivars. Acta Biologica Szegediensis, 51(1): 61-64.

Singh, D. B. (2004). Screening of pomegranate (Punica granatum L.) cultivars for arid ecosystem. Indian Journal of Agriculture Science, 74(11): 604-606.

Thakur N.S., Bhat M.M., Rana N and Joshi V.K., (2010). Standardization of pretreatments for preparation of dried arils from wild pomegranate. Journal of Food Science Technology, 47(6):620625.

Zamani, Z., sarkhosh, A., Fatahi, R., Ebadi, A., (2006). Genetic relationship among pomegranate genotype studied by fruit characteristic and RAPD markers. Journal of horticulture Science and biotechnology, 82: 11-18.

\section{How to cite this article:}

Shaili Kumari, M.R. Dinesh, B.N.S. Murthy, K.M. Shankaran, D.C. Lakshmana Reddy, K.S. Shivashankara, Kanupriya and Upreti, K.K. 2019. Correlation between Different Morphological Traits of Pomegranate (Punica grantum). Int.J.Curr.Microbiol.App.Sci. 8(01): 981-985. doi: https://doi.org/10.20546/ijcmas.2019.801.106 